\title{
Diets and Morphology of Digestive Organs of Five Species of Sea Ducks Wintering in Newfoundland
}

\author{
R. Ian Goudie* and Pierre C. Ryan*
}

\begin{abstract}
Gizzard weight, small intestine length, and caeca length were measured from specimens of sea ducks collected in coastal Newfoundland during the November to March winter seasons of 1982-88. The diets of Common Eiders (Somateria mollissima) $(\mathrm{n}=24)$, King Eiders (S. spectabilis) $(\mathrm{n}=25)$, Black Scoters (Melanitta nigra) $(\mathrm{n}=17)$, Oldsquaws (Clangula hyemalis) $(n=20)$, and Harlequin Ducks (Histrionicus histrionicus) $(n=27)$ were entirely animal matter but differed in diversity and shell component. Common Eiders, King Eiders, and Black Scoters consumed a high proportion of mollusks and sea urchins, whereas, Oldsquaws and Harlequin Ducks consumed relatively high proportions of isopods and amphipods, respectively. Interspecific differences in morphology of digestive organs, not explained by body size, were accounted for by these general differences in diet. The largest gizzards were found in scoters and Common Eiders that had the highest shell component in their diets. The shortest digestive tracts were found in Black Scoters which had the most 'specialized' diet, although there was no significant difference between Black Scoters and Harlequin Ducks. Caeca length was similar between species, except they were exceptionally short in the Black Scoter. We were unable to speculate a functional relationship of the caeca, although it may be correlated to the diversity of the diet. These results confirm other findings that morphological differences in digestive organs in waterfowl reflect dietary differences.
\end{abstract}

\section{Introduction}

Morphology of the digestive tract may reflect the diets of birds (e. g. Drobney 1984, Moss 1983, Miller 1975, Paulus 1982, Thomas 1984). Kehoe \& Ankney (1985) studied morphology of digestive organs in 5 species of diving ducks (Aythya spp.), and dismissed the concerns of Miller (1975) who thought that the rapid change in gut morphology associated with changes in diet in waterfowl could complicate efforts to imply diets from 'gut' size. Kehoe \& Ankney (1985) demonstrated the importance of adjusting the measurements of digestive organs to account for body size.

An analysis of co-variance (ANCOVA) is an appropriate method for adjusting for body size, and may be most appropriate because various organs may respond differently to varying diet components (C. D. Ankney, pers. comm.). In this paper we compare the results of an ANCOVA to those of a Principal Component Analysis (PCA) to determine if the latter method enhances the interpretation of multiple variables and groups.

\section{Materials and Methods}

Data were recorded from specimens shot by the authors and local hunters during

Received 29 May 1989, accepted 9 Aprfl 1990

* Canadian Wildlife Service, P. O. Box 9158 St. John's, Newfoundland, A1A 2X9, Canada 
each of the winters of 1982-1988 at Cape St. Mary's, southeastern Newfoundland $\left(46^{\circ} 17^{\prime} \mathrm{N}, 54^{\circ} 12^{\prime} \mathrm{W}\right)$ and Wadham Islands, northeast Newfoundland $\left(49^{\circ} 33^{\prime} \mathrm{N}, 53^{\circ} 50^{\prime} \mathrm{W}\right)$ (King Eiders only). Specimens were generally frozen within $12 \mathrm{~h}$ of collection and dissected at a later date.

Before dissection we weighed specimens $( \pm 1 \mathrm{~g})$, and measured wing lengths from notch to distal tip $( \pm 1 \mathrm{~mm})$. Measurements of digestive organs consisted of (i) gizzard weight, after contents were removed and it was towel dried (ii) small intestine length (from intersection of the caeca to the junction with the gizzard) and (iii) combined caeca length.

Most specimens had been feeding before collection. Esophageal-proventricular (gullet) contents were analyzed separately from gizzard contents, and each taxon was counted and weighed to the nearest $0.1 \mathrm{~g}$ using an electronic balance. Similar to other studies (e. g. Scott \& Olson 1972) food items of sea ducks did not deteriorate in the saline environment of the gullet at low temperatures. We used proportion of total weight of gullet contents (only gizzards used for King Eiders) to quantify the contribution of each taxon to the diet because this measurement was demonstrated to explain a large proportion of the variance (information) in diet data (after Macdonald \& Green 1984).

To highlight interspecific differences in gut morphology and diets, we pooled all sexes and age classes. We used ANCOVA, with body weight as the co-variate or independent variable, to demonstrate interspecific differences in digestive organ morphology after adjusting for body weight. A PCA was performed on the same data to attempt to reduce the subjectivity of interpreting the results of multiple univariate analyses. All variables were loge transformed to better meet assumptions of normality and homoscedacity.

Diversity indices of diets were calculated following Shannon (1948).

\section{Results}

Major differences were evident for the diets of the 5 species of sea ducks, although all species consumed mollusks to some degree. Common Eiders consumed primarily sea urchins (Strongylocentrotus droebachiensis) (55\%) and Blue Mussels (Mytilus edulis) $(30 \%)$, while King Eiders consumed sea urchins (39\%), sea stars (Asterias vulgaris) $(10 \%)$, and whelks (Buccinum undatum) (15\%) (Fig. 1). Both eider species displayed a very diverse diet compared to Black Scoters, which appeared 'specialized' to Blue Mussels (98\%) (Table 1). The smaller Oldsquaws and Harlequin Ducks had the most diverse diets (Table 1), and consumed relatively high proportions of isopods (Idotea baltica) $(40 \%)$ and amphipods (predominantly Gammarellus angulosus, Calliopsius laeviusculus) (45\%), respectively (Fig. 3 in Goudie \& Ankney 1986).

An ANOVA of digestive organs indicated that most digestive organs differed significantly in size between species (Table 2). There were interspecific differences in digestive organ morphology that could not be accounted for by body size, such as the relatively short intestine length in Black Scoters (Table 3). In each ANCOVA there were no interspecific differences in the slopes of the regressions relating digestive organ morphology to body weight, and the slopes were significantly different from zero, with the 


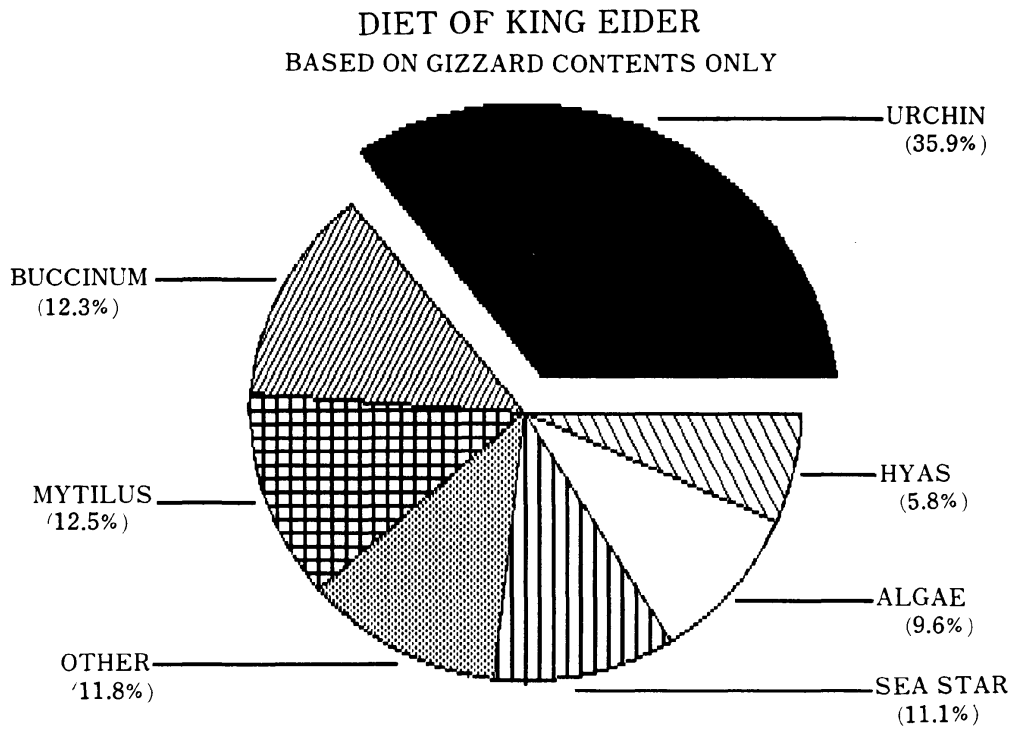

Figure 1a. Diet of King Eiders collected in coastal Newfoundland in winter 1982-1988. Data based on gizzard contents only.

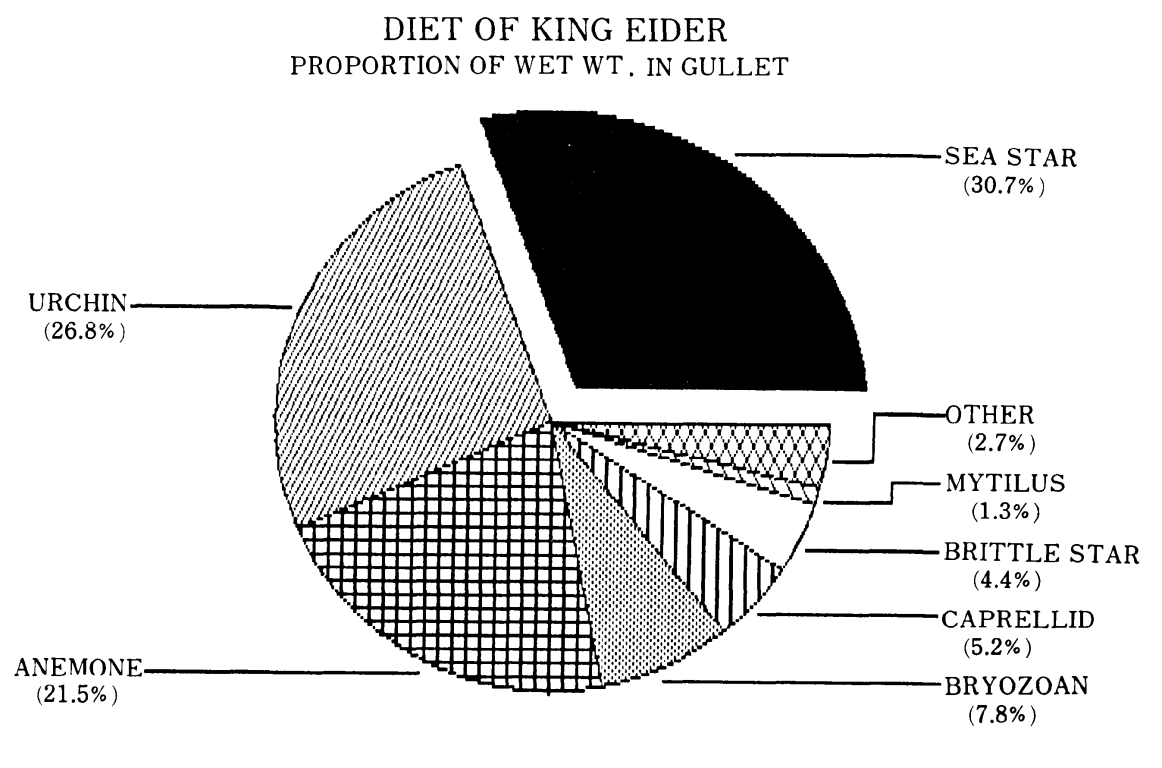

+ NOT INCLUDING ALGAE

Fibure 1b. Diet of King Eiders collected in coastal Newfoundland in winter 1982-1988. Based on gullet contents only. Note that valuefor algae has been excluded but was $6.7 \%$ when factored in. 
Table 1. Relative diversity $(\mathrm{J})$ of diets of sea duck specimens collected in coastal Newfoundland, 1982-1988.

\begin{tabular}{ccccc}
\hline \hline Common Eider & King Eider & Black Scoter & Oldsquaw & Harlequin Duck \\
\hline 0.56 & 0.50 & 0.12 & 0.69 & 0.75 \\
\hline
\end{tabular}

Where: $J=H^{\prime} / H(\max )$

Shannon (1948) (s) $H^{\prime}=-\sum_{i=1} P i \log P i$

$H(\max )=\log ($ no. of prey items)

Table 2. Results of Analyses of Variance (ANOVA) of digestive organs of five species of sea ducks Wintering in Newfoundland.

\begin{tabular}{lccccrc}
\hline \hline \multicolumn{1}{c}{ Species } & $\mathrm{N}$ & $\begin{array}{c}\text { Mass } \\
(\mathrm{g}) 1 / \pm \mathrm{s} . \mathrm{d} .\end{array}$ & $\begin{array}{c}\text { Gizzard } \\
(\mathrm{g}) \pm \mathrm{s} . \mathrm{d} .\end{array}$ & $\begin{array}{c}\text { Small Intestine } \\
(\mathrm{cm}) \pm \mathrm{s} . \mathrm{d} .\end{array}$ & $\begin{array}{c}\text { Cacae Length } \\
(\mathrm{cm}) \pm \mathrm{s} \text { d. }\end{array}$ & $\begin{array}{c}\text { Liver } \\
(\mathrm{g}) \pm \mathrm{s} . \mathrm{d} .\end{array}$ \\
\hline Common Eider & 24 & $1810.0 \pm 171$ & $87.3 \pm 23.0$ & $209.3 \pm 13$ & $25.9 \pm 2.7$ & $69.7 \pm 10.1$ \\
King Eider & 25 & $1425.2 \pm 95.7$ & $44.3 \pm 6.7^{\mathrm{a}}$ & $187.1 \pm 15.9$ & $28.9 \pm 4.1$ & $54.5 \pm 9.5$ \\
Black Scoter & 17 & $1038.4 \pm 87.1$ & $42.8 \pm 3.9^{\mathrm{a}}$ & $156.2 \pm 12.4$ & $4.2 \pm 0.9$ & $41.5 \pm 7.2$ \\
Oldsquaw & 20 & $758.8 \pm 94.6$ & $22.3 \pm 3.6$ & $170.6 \pm 14.8$ & $20.1 \pm 3.0$ & $37.6 \pm 9.5$ \\
Harlequn Duck & 27 & $610.7 \pm 66.1$ & $16.0 \pm 3.6$ & $145.3 \pm 10.2$ & $18.1 \pm 2.0$ & $27.0 \pm 4.1$ \\
\hline
\end{tabular}

1/ No significant differences between means with corresponding letters in the individual columns.

Table 3. Results of Analyses of Covariance (ANVOVA) of digestive organs of five species of sea ducks wintering in Newfoundland.

\begin{tabular}{|c|c|c|c|c|c|c|}
\hline \multirow[b]{2}{*}{ Species (n) } & & \multirow{2}{*}{$\begin{array}{l}\text { Covariate } \\
\text { Mean Mass }\end{array}$} & \multicolumn{4}{|c|}{ Dependent Vairables $^{1}$} \\
\hline & & & $\begin{array}{c}\text { Gizzard }^{2} \\
\text { Weight }\end{array}$ & $\begin{array}{l}\text { Small Intestine } \\
\text { Length }\end{array}$ & $\begin{array}{l}\text { Caecae } \\
\text { Length }^{3}\end{array}$ & Liver WT \\
\hline Common Eider & (24) & $1810.0 \pm 171$ & $55.3 \pm 1.10$ & $191.5 \pm 1.04(\text { s.e. })^{\mathrm{a}}$ & $25.3 \pm 1.09^{a}$ & $43.4 \pm 1.10^{\mathrm{a}}$ \\
\hline King Eider & (25) & $1425.2 \pm 95.7$ & $34.3 \pm 1.06^{\mathrm{a}}$ & $177.5 \pm 1.03^{\mathrm{ed}}$ & $28.3 \pm 1.06$ & $41.2 \pm 1.06^{\mathrm{a}}$ \\
\hline Black Scoter & (17) & $1038.4 \pm 87.1$ & $42.8 \pm 1.04$ & $155.8 \pm 1.02^{\mathrm{b}}$ & $4.0 \pm 1.04$ & $42.0 \pm 1.04^{\mathrm{a}}$ \\
\hline Oldsquaw & (20) & $758.8 \pm 94.6$ & $28.3 \pm 1.06^{\mathrm{a}}$ & $178.9 \pm 1.03^{\mathrm{ac}}$ & $20.1 \pm 1.06^{\mathrm{ab}}$ & $47.9 \pm 1.07^{\mathrm{a}}$ \\
\hline Harlequin D. & (27) & $610.7 \pm 66.1$ & $23.8 \pm 1.01$ & $157.8 \pm 1.04^{b d}$ & $18.3 \pm 1.09^{\mathrm{b}}$ & $42.0 \pm 1.10^{\mathrm{a}}$ \\
\hline
\end{tabular}

${ }^{1}$ Scaled to body weight by ANCOVA

${ }^{2}$ No significant differenced $(\mathrm{P}>0.05)$ between means with corresponding letters in the individual columns.

3 Regression on body mass not significant and slopes of regression lines not equal.

exception in both cases for the relationship between caecae length and body mass.

The results of the ANCOVA indicated that gizzard size was relatively heavier in the Common Eiders and Black Scoters (Table 3) and thes species displayed the highest shell component in their diets (Goudie \& Ankney 1986). Harlequin Ducks and Black Scoters had relatively short intestines (Table 3 ).

Plots of principal component scores provided a display that could be interpreted in relation to the derived components (Table 4). PC1 explained $59.7 \%$ of the variance and was interpreted as a body size component, although positive allometry (gizzard) and negative allometry (intestine length) were indicated (see Anderson 1963, Pimentel 1979, Goudie \& Ankney 1986). We noted however that the placement of Black 


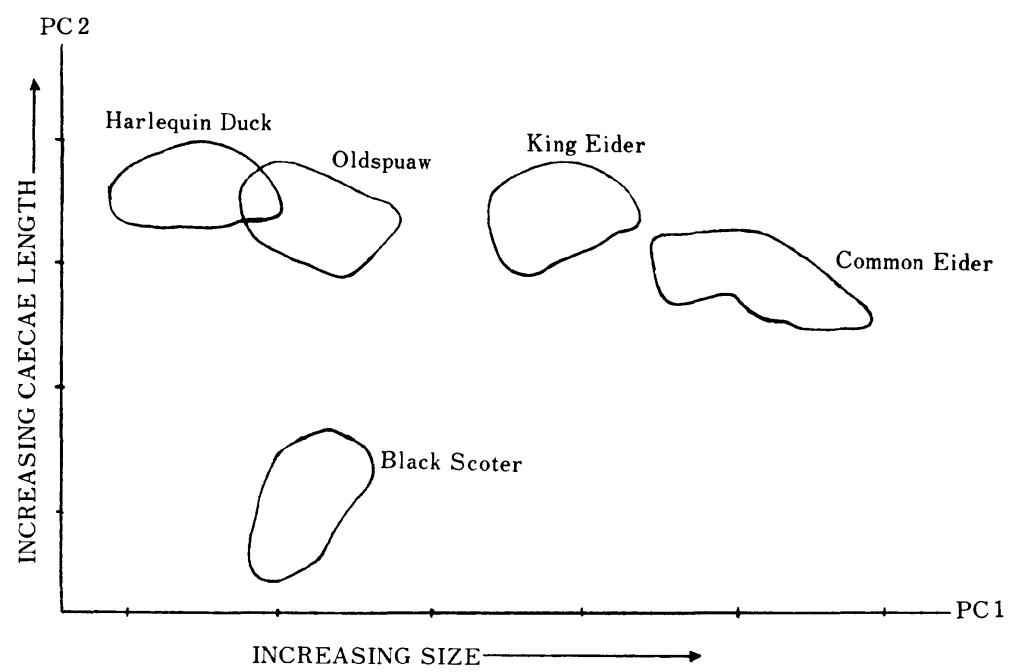

Figure 2. Principal commponent score plot based on PC 1 and PC 2 for 4 morphological measures (see Table 4) of sea duck specimens collected in coastal Newfoundland, winters 19821988. Polygons represent dispersions of principal scores for species.

Table 4. Principal component loadings for analysis of digestive organ morphology of five species of seaducks wintering in coastal Newfoundland.

\begin{tabular}{|c|c|c|c|c|c|c|}
\hline \multicolumn{7}{|c|}{ Component Loadings } \\
\hline & $\mathrm{PC} 1$ & $\mathrm{r}^{1}$ & $\mathrm{PC} 2$ & $\mathrm{r}$ & PC3 & $\mathrm{r}$ \\
\hline Mass $^{2}$ & 0.516 & $0.625^{*}$ & -0.143 & -0.140 & 0.837 & 0.140 \\
\hline $\begin{array}{l}\text { Intestine } \\
\text { Length }\end{array}$ & 0.169 & $0.342^{*}$ & 0.026 & 0.043 & 0.037 & 0.010 \\
\hline $\begin{array}{l}\text { Gizzard } \\
\text { Weight }\end{array}$ & 0.745 & $0.737^{*}$ & -0.382 & $-0.306^{*}$ & -0.538 & -0.073 \\
\hline $\begin{array}{l}\text { Caeca } \\
\text { Length }\end{array}$ & 0.387 & $0.378 t$ & 0.913 & $0.721^{*}$ & -0.95 & -0.013 \\
\hline $\begin{array}{l}\text { Eigen } \\
\text { Values }\end{array}$ & 0.630282 & & 0.412883 & & 0.011953 & \\
\hline $\begin{array}{l}\text { Variance } \\
\text { Explained }\end{array}$ & $59.7 \%$ & & $38.9 \%$ & & $1.1 \%$ & \\
\hline
\end{tabular}

Scoters on PCl was not entirely relative to body size suggesting some other information may have been encompassed in this component (Fig. 2). PC2 explained 38.9\% of the variance, and was interpreted to primarily represent cecae length (Table 4). This indicated the extremely small cecae length in Black Scoters relative to the other species but did not clearly demonstrate the relatively larger caeca in King Eiders (see Table 3 ). 


\section{Discussion}

Differences in digestive organ morphology of sea ducks wintering in coastal Newfoundland that were not explained by differences in body mass can be explained by dietary differences. Kehoe \& Ankney (1985) demonstrated that of 5 species of diving ducks (Aythya spp.) the heaviest gizzards were in the species (Aythya americana) with the highest fibre content in its diet. Our results indicated a tendency for the heaviest gizzards to occur in the species with the highest shell component in diets, i. e., Common Eiders and Black Scoters. The relatively light gizzard of the King Eider was somewhat of an anomaly considering the high shell component for the diet indicated by the gizzard contents (Fig. 1a). However, we were concerned that those contents may have been biased (see Swanson \& Bartonek 1970) because our limited sample of gullet contents of King Eiders indicated a higher shell free component (Fig. 1b).

Moss (1983) suggested that species could reduce metabolic costs by having the shortest possible digestive tracts for a given diet. He found that ptarmigan (Lagopus spp.) with diverse diets had the longest intestines, and suggested this enabled them to digest whatever foods were available at a given time. Kehoe \& Ankney (1985) found the longest digestive tracts occurred in the scaups (Aythya marila, A. affins) which had relatively diverse diets of plant and animal matter. We found relatively short digestive tracts in Black Scoters which were 'specialists' on Blue Mussels so this pattern may hold for waterfowl displaying diets of only animal matter. We were unable to account for the relatively small intestine length indicated for Harlequin Ducks, but suspect that length of digestive tract could be affected by relative shell component in diet as well as diversity, i. e., a larger digestive tract may be required to process digestible foods from fragmented mollusk shells.

The function of the caeca in waterfowl is poorly understood (Drobney 1984) but some others correlate relatively large caeca to increased fiber content in the diet (e. g. Kehoe \& Ankney 1985, Keho et al. 1988). We noted smaller adjusted lengths in caeca in sea ducks we studied relative to the 5 species of diving ducks studied by Kehoe \& Ankney (1985). The sea ducks we studied consumed little or no vegetable matter, and trace specimens were generally considered as incidental but we noted a significant presence of coralline algae and Ptilota serrata in King Eiders $(9.6 \%)$, and this species demonstrated the longest caeca. The extremely short caeca in Black Scoters are unlikely to be attributed to diets alone, and we suspect that interspecific differences exist for this organ within the sea duck tribe (Mergini, after Johnsgard 1960) because we were unable to establish a linear relationship between caeca lengths and body mass (see Table 3).

In conclusion, we found that there were interspecific differences in morphology of digestive organs of 5 species of sea ducks wintering in coastal Newfoundland. Similar to other studies (e. g. Kehoe \& Ankney 1985), we demonstrated that some of these differences were due to differences in total body size, and it was only valid to relate differences in morphology to diets after correcting for body weight differences. We attempted to reduce the subjectivity of interpreting multiple Analyses of Co-variance of digestive organ size by applying a Principal Component Analysis, and felt that the interpretation of the latter is more ambiguous. 


\section{Acknowledgements}

Special thanks to Dermot Dohey, Patrick Barry, Alisausus McGrath and Cyril McGrath for providing some of the specimens used in this study. Further thanks to Dermot and Mildred Dohey and the Kehoe Family for the great hospitality. Thanks to Pat Kehoe and Dave Ankney for commenting on a previous draft of this manuscript.

\section{Literature cited}

Anderson, T. W. 1963. Asymptotic theory for principal component analysis. Annals of Mathematics and statistics 34: 122-148.

Drobney, R. D. 1984. Effect of diet on visceral morphology of breeding Wood Ducks. Auk, 101:

Goudie, R. I. \& Ankney, C. D. 1986. Body size, activity budgets, and diets of sea ducks wintering in Newfoundland. Ecology 67(6): 1475-1484.

Johnsgard, P. A. 1960. Classification and evolutionary relationships of the sea ducks. Condor 62: $426-433$.

Kehoe, F. P. \& Ankney, C. D. 1985. Variation in digestive organ size among five species of diving ducks (Aythya spp.). Canadian J. Zool. 63(10): 2339-2342.

Kehoe, F. P., Ankney, C. D. \& Alussauskas, R. P. 1988. Effects of dietary fiber, diet diversity on digestive organs of captive mallards. Canadian J. Zool. 66: 1597-1602.

Paulus, S. L. 1982. Gut morphology of gadwalls in Louisiana in winter. J. Wildlife Management 46: 483-489.

Pimentel, R. A. 1979. Morphometrics; the multi-variate analysis of biological data. Kendall/Hunt, Dubuque, Iowa, USA.

Macdonald, J. S. \& Green, R. H. 1983. Redundancy of variables used to describe importance of prey items in fish diets. Canadian J. Fisheries and Aquatic Sciences 40: 635-637.

Miller, M. R. 1975. Gut morphology of mallards in relation to diet quality. J. Wildlife Management 39: 168-173.

Moss. R. 1983. Gut size, body weight, and digestion of winter foods by grouse and ptarmigan. Condor 85: $185-193$.

Shannon, C. E. 1948. A mathematical theory of communication. Bell System Technical Journal 27: 379-423, 623-656.

Stott, R. S. \& Olson, D. P. 1972. Food-habit relationships of sea ducks on the New Hampshire coastline. Ecology 54(5): 996-1007.

Swanson, G. A. \& Bartonek, J. C. 1970. Bias associated with food analysis in gizzards of blue-winged teal. J. Wildlife Management 34: 739-746.

Thomas, V. G. 1984. Winter diet and intestinal proportions of rock and willow ptarmigan and sharptailed grouse in Ontario. Canadian J. Zool. 62: 2258-2263. 


\section{ニューファウンドランドで越冬する海鴨 5 種の食性と消化器官の形態}

1982 年から 88 年にかけてニューファウンドランド沿岸で冬期に採集した 5 種の海鴨（ホンケワタガ モ, ケワタガモ, クロガモ, コオリガモ, シノリガモ) の食性と消化器官 (砂鐜重量, 小腸・盲腸の長さ) を調査した。5 種類とも浪とんど動物質の䬣を食べていたが，ホンケワタガモ，ケワタガモ，クロガモが 貝類とウニ類を高い割合で食べていたのに対し，コオリガモとシノリガモは等脚類と端脚類を比較的多く 食べていた。消化器官の計測値は体の大きさに関係なく，食性の違いによって種間での差異がみられた。

（文責＼cjkstart柿澤亮三）

Goudie, R.I., Ryan, P.C.; カナダ野生生物局，私書箱 9158, セントジョーンズ, ニューファウンドランド，カナダ 